\title{
URGENSI PENGUATAN BUDAYA WIRAUSAHA UNTUK MENINGKATKAN DAYA SAING INDONESIA DI ERA MEA
}

\author{
Agus Prianto \\ STKIP PGRI Jombang, Indonesia \\ Email:pimpinan1@yahoo.co.id
}

\begin{abstract}
Abstrak: Urgensi Penguatan Budaya Wirausaha untuk Meningkatkan Daya Saing Indonesia di Era MEA. Masyarakat Ekonomi ASEAN (MEA) akan diberlakukan mulai Desember 2015. Berbagai hambatan yang selama ini menghalangi pergerakan berbagai sumber daya dan aktivitas ekonomi seperti kebijakan tarif dan non tarif mulai ditiadakan. Konsekuensinya tingkat persaingan di kawasan ASEAN akan semakin ketat. Pertanyaannya adalah apakah Indonesia sudah siap menghadapi MEA? Budaya wirausaha yang belum kuat dikhawatirkan akan mempengaruhi kemampuan Indonesia untuk memanfaatkan potensi pasar domestik yang sangat besar. Hal ini menjadi peringatan bahwa dalam MEA nanti penetrasi produk luar ke pasar dalam negeri akan semakin massif. Untuk memperkuat daya saing bangsa, pemerintah harus mendorong agar kewirausahaan menjadi budaya baru dalam kehidupan masyarakat Indonesia. Hal ini dapat dilakukan dengan melibatkan lembaga pendidikan, mulai dari tingkat dasar sampai dengan pendidikan tinggi; meningkatkan anggaran penelitian dan pengembangan, serta menggalakkan pelatihan kewirausahaan.
\end{abstract}

Kata kunci: Daya saing, Masyarakat Ekonomi ASEAN, budaya wirausaha

\begin{abstract}
Urgency of Entrepreneurial Culture Strengthening to Improve Indonesia Competitiveness toward ASEAN Economic Community (AEC). ASEAN Economic Community (AEC) will be implemented starting December 2015. Many obstacles that have hindered the movement of resources and economic activities such as tariff and non-tariff are abolished. As a result of that policy the level of competition in the ASEAN region will be intense. The question is whether Indonesia is ready to face the MEA? A weak entrepreneurial culture will affect the ability of Indonesia to exploit the potential of a large domestic market. To strengthen the competitiveness of Indonesia, government should encourage a new culture of entrepreneurship. This can be done by involving educational institutions from elementary to higher education, increasing research and development budget, and promoting entrepreneurship training.
\end{abstract}

Keywords: competitiveness, ASEAN Economic Community, entrepreneurship culture.

\section{PENDAHULUAN}

Implementasi ASEAN Economic Community $(A E C)$, atau boleh disebut sebagai pasar tunggal ASEAN akan segera diberlakukan pada akhir 2015. Ini merupakan tonggak awal dari diberlakukannya kawasan perdagangan bebas di kawasan ASEAN. Pemberlakuan AEC membawa implikasi pada adanya kebebasan arus barang, jasa, modal, dan sumber daya manusia untuk keluar masuk (free exit and free entry) di berbagai negara kawasan ASEAN. Berbagai hambatan yang selama ini menghalangi pergerakan berbagai sumber daya dan aktivitas ekonomi di kawasan ASEAN, seperti kebijakan tarif dan non tarif mulai ditiadakan. Dengan demikian semua negara di kawasan ASEAN memiliki peluang yang sama untuk menjadi 
basis kegiatan produksi barang dan jasa, apabila menurut kalkulasi ekonomi dinilai menguntungkan (www.asean.org).

Hingga saat ini masih terdengar suara kegalauan tentang kesiapan Indonesia untuk menghadapi AEC. Sebenarnya keraguan untuk menghadapi AEC tidak hanya dirasakan oleh Indonesia, tetapi juga dirasakan oleh Thailand (www.kriengsak.com), Phillipina (www.veteransbank.com), dan Vietnam (www.icird.org). Meskipun demikian dari berbagai media online kita membaca berbagai upaya dilakukan oleh negara tetangga tersebut untuk mempersiapkan diri menghadapi AEC. Pembangunan berbagai sarana infrastruktur seperti jalan, rel kereta api, pelabuhan, dan telekomunikasi terus dikembangkan. Bahkan Thailand dan Vietnam juga mengembangkan soft infrastruktur, berkaitan dengan kemampuan berbahasa Inggris dari para warganya. Untuk menyiapkan warganya menghadapi AEC, Thailand meluncurkan "English Speaking Year 2012" (www.etc-thai.com). Thailand menyadari sangat tertinggal dalam hal penguasaan bahasa Inggris yang sudah menjadi bahasa pergaulan di tingkat global. Oleh karena itu, melalui program "English Speaking Year 2012" pemerintah Thailand berharap akan dapat mendorong para warganya untuk mampu berinteraksi dengan sesama bangsa di kawasan dan di tingkat global.

Indonesia sesungguhnya memiliki keunggulan komparatif bila dibandingkan dengan sesama negara anggota ASEAN. Hal ini terutama berkaitan dengan jumlah penduduk terbesar dibandingkan dengan negara ASEAN lainnya. Indonesia juga kaya dengan sumber daya alam, kaya budaya, dan kaya dengan berbagai tempat-tempat yang indah dan eksotis yang bila mampu dikemas dengan sungguh-sungguh dapat dijual dalam kegiatan kepariwisataan. Lokasi Indonesia yang sangat strategis, yang berada di antara dua samudra dan dua benua seharusnya juga bisa mendudukkan Indonesia sebagai pusat perdagangan di kawasan ASEAN.

Pertanyaannya adalah apakah para pelaku usaha bisnis dan sumber daya manusia di Indonesia sudah memiliki kesiapan untuk bersaing secara head to head dengan pelaku usaha sejenis dari negara kawasan ASEAN? Artikel ini bermaksud untuk melakukan analisis kesiapan Indonesia dalam menyongsong kehadiran AEC yang akan efektif diberlakukan pada akhir tahun 2015. Untuk menganalisis kesiapan Indonesia menghadapi AEC, tulisan ini akan menyajikan berbagai data, terutama yang berkaitan dengan kinerja perekonomian Indonesia. Berbagai data tersebut kemudian secara head to head akan dikomparasikan dengan data sejenis dari beberapa negara anggota ASEAN. Hasil komparasi berbagai data inilah yang dijadikan sebagai dasar untuk melihat kesiapan Indonesia dalam menghadapi AEC.

\section{SEKILAS TENTANG KEKUATAN PEREKONOMIAN INDONESIA}

Berbagai analisis dari berbagai lembaga keuangan internasional memprediksi Indonesia akan menjadi salah satu kekuatan ekonomi dunia. Pada saat ini Indonesia masuk dalam kelompok $\mathrm{G} 20$, yaitu kelompok negara yang merepresentasikan 90\% GDP global, $80 \%$ volume perdagangan internasional, dan $2 / 3$ total jumlah 
Tabel 1. Indikator Utama Daya Saing Negara ASEAN

\begin{tabular}{ccccc}
\hline \multirow{3}{*}{ Negara } & \multicolumn{4}{c}{ Indikator Utama Daya Saing } \\
\cline { 2 - 5 } & $\begin{array}{c}\text { Jumlah } \\
\text { Penduduk (juta) }\end{array}$ & $\begin{array}{c}\text { GDP } \\
(\$ \text { miliar })\end{array}$ & $\begin{array}{c}\text { IPC } \\
(\$)\end{array}$ & $\begin{array}{c}\text { Proporsi } \\
\text { GDP Dunia (\%) }\end{array}$ \\
\hline Indonesia & 242,3 & 878,2 & 3.592 & 1,46 \\
Malaysia & 28,9 & 303,5 & 10.304 & 0,60 \\
Singapura & 5,2 & 276,5 & 51.162 & 0,39 \\
Thailand & 69,5 & 365,6 & 5.678 & 0,78 \\
Phillipina & 94.95 & 250,4 & 2.614 & 0,51 \\
Vietnam & 87,8 & 138,1 & 1.528 & 0,39 \\
\hline
\end{tabular}

Sumber: The Global Competitiveness Report 2013-2014, WEF 2013

penduduk dunia (www.G20.org). Potensi Indonesia untuk menjadi salah satu kekuatan ekonomi dunia sangat besar. Di antara negara anggota G20 pada tahun 2012 dan 2013, Indonesia menjadi negara dengan pertumbuhan ekonomi tertinggi kedua setelah China. Selama 5 tahun, antara 20092013 pertumbuhan ekonomi Indonesia ratarata mencapai $5,9 \%$ per tahun. Dengan didukung oleh wilayah yang luas, mayoritas jumlah penduduk dalam kelompok usia produktif, dan sumber daya alam yang melimpah; maka peluang Indonesia untuk menjadi kekuatan ekonomi dunia sangat terbuka lebar (www.bbc.co.uk/indonesia).

Tabel 1 menggambarkan indikator utama perekonomian Indonesia dibandingkan dengan beberapa negara anggota ASEAN. Pertumbuhan ekonomi Indonesia yang positif selama beberapa tahun terakhir berdampak langsung terhadap meningkatnya pendapatan per kapita (IPC) dan penurunan angka pengangguran. Peningkatan rerata IPC dan berkurangnya angka pengangguran merupakan indikator meningkatnya kesejahteraan masyarakat. IMF melaporkan adanya peningkatan pendapatan per kapita penduduk dari $\$ 2,329$ (2009) menjadi $\$ 3,660$ (2012).
Artinya selama 3 tahun ada peningkatan IPC sebesar 57.15\%. Pada akhir tahun 2013, diperkirakan IPC meningkat pada kisaran \$4.400-\$4.500 (www.imf.org).Peningkatan IPC berdampak pada pengeluaran konsumsi, dan selanjutnya berdampak pada tumbuhnya kegiatan usaha-bisnis. Tumbuhnya kegiatan usaha berpengaruh pada besaran produk domestik bruto (PDB). Pada tahun 2010 World Bank melaporkan PDB Indonesia sebesar $\$ 834.300$ miliar, dan berada pada urutan 17 dari kelompok negara G20. Tahun 2011 PDB Indonesia tercatat $\$ 845.680$ miliar dan menempatkan Indonesia pada urutan 16 dari kelompok negara G20 (www.worldbank.org). Selanjutnya IMF memprediksi pada tahun 2015 PDB Indonesia akan mencapai $\$ 1,172.10$ miliar dan diprediksi akan masuk 10 besar dunia (www.imf.org).

Meningkatnya rerata IPC telah membentuk kelompok masyarakat yang masuk dalam kategori kelompok kelas menengah (middle class economy). Jumlah orang di Indonesia dengan pengeluaran rumah tangga di atas Rp. 5 juta per bulan diprediksi akan bertambah hingga 250\%. Menurut Antony Suwandy, Direktur Retail Banking PT Bank ANZ Indonesia; jumlah 
populasi untuk segmen ini akan mencapai 23,4 juta jiwa pada tahun 2020. Kaum elit dengan pengeluaran lebih dari Rp. 7,5 juta per bulan juga akan naik menjadi 6,9 juta jiwa (www.tempo.com). Secara keseluruhan, populasi kelas menengah hingga kaum elit di Indonesia pada tahun 2020 diprediksi mencapai 141 juta jiwa (www.tempo.com). Hingga saat ini, kelompok masyarakat berpendapatan menengah inilah yang berkontribusi pada semaraknya kegiatan konsumsi di dalam negeri. Sebagaimana dilaporkan oleh BPS, sampai dengan tahun 2013, kontribusi kegiatan konsumsi masyarakat bagi pertumbuhan ekonomi Indonesia berada pada kisaran angka 50\% (www.bps.go.id).

Bank Indonesia membuat laporan senada. Jumlah kelas menengah di Indonesia telah melampaui angka $60 \%$ dari total penduduk Indonesia (www.investor.co.id), dan hal ini akan menjadi penggerak konsumsi domestik, sekaligus menjadi penopang utama pertumbuhan ekonomi Indonesia. BPS melaporkan bahwa antara tahun 2010 sampai dengan 2012 konsumsi masyarakat menyumbang pertumbuhan PDB masing-masing sebesar 56,6\%; 54,6\%; dan $54,8 \%$ (www.bps.go.id). Namun demikian, meningkatnya konsumsi domestik bila tidak diimbangi dengan peningkatan produktivitas di sektor domestik menjadi penyebab membengkaknya angka impor. Dengan demikian ada satu permasalahan penting yang harus dijawab oleh Indonesia seiring dengan meningkatnya jumlah kelas menengah, yaitu apakah meningkatnya jumlah kelas menengah segera diiringi dengan meningkatnya produktivitas nasional.
Meningkatnya pendapatan per kapita dalam 3 tahun terakhir sebesar $57.15 \%$ pasti akan berdampak langsung pada meningkatnya pengeluaran konsumsi masyarakat. Data dari Biro Pusat Statistik (BPS) menunjukkan bahwa dalam rentang 3 tahun, antara 2010 sampai dengan 2012 pengeluaran konsumsi masyarakat merupakan komponen utama pembentuk PDB, dengan kontribusi sebesar 55\% (www.bps.go.id). Dengan menggunakan asumsi rerata pengeluaran kelas menengah Rp. 5 juta per bulan; dengan jumlah kelas menengah sebanyak 150 juta jiwa maka besaran konsumsi agregat per bulan akan setara Rp. 750 triliun atau Rp. 9.000 triliun per tahun. Nilai konsumsi ini adalah hampir setara dengan lima kali lipat jumlah belanja negara pada APBN 2013 sebesar Rp. 1.683,011 triliun (Data Pokok APBN 20072013, Kemenkeu RI). Meningkatnya jumlah kelas menengah di Indonesia berdampak besar pada ukuran ekonomi Indonesia. Hal ini juga menggambarkan betapa besarnya potensi aktivitas ekonomi yang dapat dikreasikan oleh para pelaku usaha di Indonesia.

Selain mendorong pertumbuhan ekonomi melalui aktivitas konsumsi, kelompok masyarakat kelas menengah yang memiliki latar belakang pendidikan memadai diharapkan mampu memanfaatkan kesempatan untuk mengembangkan kegiatan usaha dalam rangka memenuhi kebutuhan masyarakat. Dalam konteks inilah keberadaan kelompok masyarakat yang memiliki spirit entrepreneurship sangat diharapkan kehadirannya. Hal ini merupakan pekerjaan rumah bagi perekonomian Indonesia, bagaimana caranya agar spirit 
Tabel 2. Peringkat Kualitas Perekonomian Indonesia dan Beberapa Negara ASEAN Tahun 2011 (Dari 110 Negara di Dunia)

\begin{tabular}{lccc}
\hline Negara & $\begin{array}{c}\text { Kualitas } \\
\text { Pertumbuhan }\end{array}$ & $\begin{array}{c}\text { Kualitas Aktifitas } \\
\text { Ekonomi }\end{array}$ & $\begin{array}{c}\text { Kewirausahaan dan } \\
\text { Peluang Kerja }\end{array}$ \\
\hline Singapura & 16 & 1 & 14 \\
Malaysia & 43 & 17 & 36 \\
Thailand & 45 & 13 & 53 \\
Vietnam & 62 & 40 & 78 \\
Phillipina & 66 & 43 & 70 \\
Indonesia & 70 & 44 & 80 \\
\hline
\end{tabular}

Sumber: www.prosperity.com/rankings.aspx

entrepreneurship menjadi gaya hidup baru; terutama bagi para kawula muda. Spirit entrepreneurship yang mengakar kuat dalam kehidupan masyarakat sangat diperlukan agar membesarnya potensi ekonomi Indonesia benar-benar dapat dimanfaatkan oleh para pelaku ekonomi domestik. Kelompok inilah yang kelak akan ikut menggelembungkan aktivitas ekonomi di Indonesia, sehingga dapat dihadirkan pertumbuhan ekonomi yang berkelanjutan.

Indonesia sangat membutuhkan keberadaan para entrepreneur dalam skala besar, karena kelompok inilah yang akan mampu menciptakan budaya kerja baru dan meningkatkan produktivitas kerja. Dalam artikelnya yang berjudul "How to avoid middle-income traps? Evidence from Malaysia" (www.voxeu.org), Aaron Flaaen, Ejaz Ghani, dan Saurabh Mishra juga memberikan penjelasan bahwa untuk menghindari jebakan kelas menengah maka diperlukan adanya budaya kerja baru dan kemampuan berinovasi guna mendukung peningkatan produktivitas nasional. Penguatan budaya wirausaha merupakan salah satu strategi yang dapat ditempuh untuk meningkatkan produktivitas nasional.

\section{PENTINGNYA PENGUATAN BUDAYA WIRAUSAHA}

Data-data berikut ini juga dapat dijadikan pertimbangan pentingnya mendorong kelompok kelas menengah untuk memiliki life style baru di bidang kewirausahaan. Meskipun pada saat ini lebih dari 50\% dari penduduk Indonesia termasuk dalam kelompok kelas menengah, dan pada tahun 2015 Indonesia diprediksi oleh IMF akan masuk dalam kelompok negara dengan PDB 10 besar dunia; namun hingga tahun 2011 kualitas pertumbuhan ekonomi Indonesia masih tertinggal bila dibandingkan dengan beberapa negara ASEAN. Tabel 6 menjelaskan tentang perbandingan kualitas pertumbuhan ekonomi Indonesia dengan beberapa negara ASEAN.

Tabel 2 menunjukkan adanya keterkaitan antara peringkat aktivitas kewirausahaan dengan terbukanya peluang kerja, kualitas pertumbuhan, dan kualitas aktivitas ekonomi. Spirit kewirausahaan di Indonesia masih tertinggal bila dibandingkan dengan beberapa negara ASEAN. Saat ini jumlah pewirausaha di Indonesia dinilai masih kecil dibandingkan dengan jumlah penduduk. 
Idealnya, minimal 2\% dari 247 juta jiwa penduduk Indonesia merupakan kaum pewirausaha. Kalau harapan minimal ini bisa diwujudkan, maka akan ada sekitar 5 juta pewirausaha di Indonesia. Data per Januari 2012 menunjukkan bahwa jumlah pewirausaha di Indonesia baru sebesar $1,56 \%$ dari total penduduk. Sebagai perbandingan, komposisi pewirausaha dibandingkan jumlah penduduk di Singapura sebesar 7,2\%, Malaysia sebesar $4 \%$, dan Thailand sebesar $4,1 \%$ dari total penduduk (www.pikiran-rakyat.com). Seiring dengan menggelembungnya ukuran ekonomi Indonesia, yang ditandai dengan meningkatnya rerata IPC dan PDB, ada satu pekerjaan utama yang harus dibangun oleh Indonesia; yaitu menumbuhkan semangat berwirausaha.

Peningkatan spirit berwirausaha sangat diperlukan agar kualitas pertumbuhan ekonomi Indonesia dapat ditingkatkan. Peningkatan pertumbuhan ekonomi, IPC, dan PDB akan lebih bermakna apabila diikuti dengan terbukanya peluang kerja di dalam negeri. Hingga saat ini masih muncul situasi paradoks, karena meningkatnya pertumbuhan ekonomi, IPC, dan PDB masih diikuti dengan besarnya jumlah pengangguran. Mengacu data yang dipublikasikan oleh BPS, Jumlah pengangguran terbuka di Indonesia per Agustus 2013 tercatat 7.39 juta orang (www.tribunnews.com).

$$
\text { Untuk mengatasi problem }
$$
ketenagakerjaan dalam jangka panjang, dan dalam rangka memperkuat perekonomian Indonesia dalam menghadapi AEC, gerakan kewirausahaan nasional harus menjadi prioritas utama, dilakukan secara masif, dan perlu dijadikan headline dalam pengembangan ekonomi nasional. Untuk itu diperlukan penguatan sinergi antara pemerintah (mulai dari pemerintah pusat sampai pada level desa), lembaga pendidikan (mulai dari pendidikan dasar sampai dengan pendidikan tinggi), dan berbagai lembaga swadya masyarakat; agar terbangun persepsi yang kuat di masyarakat tentang pentingnya lifestyle baru: menjadi pewirausaha. Dengan angka koefisien kewirausahaan di Indonesia yang baru mencapai 1,56\% dari total jumlah penduduk yang mencapai 250 juta, maka diasumsikan jumlah pewirausaha hanya mencapai 3,9 juta pewirausaha. Dengan jumlah angkatan kerja yang mencapai 118,2 juta jiwa, maka diasumsikan setiap pewirausaha harus menanggung beban ketenagakerjaan mencapai 30 tenaga kerja. Beban pewirausaha di Indonesia untuk menampung tenaga kerja menjadi sangat berat.

Masalah pengangguran dan kemiskinan di Indonesia dapat diurai bila dapat dikreasikan koefisien kewirausahaan minimal 2,5\% dari total penduduk. Semakin tinggi jumlah pewirausaha di Indonesia, semakin besar pula jumlah lapangan pekerjaan yang dapat diciptakan, sehingga angka pengangguran dapat dikurangi; dan kesejahteraan masyarakat dapat ditingkatkan. Dalam era AEC keberadaan pewirausaha akan menjadi penyangga utama penggerak perekonomian dan penopang daya saing bangsa. Indonesia dituntut bekerja keras untuk membuat kewirausahaan sebagai lifestyle baru untuk menghadapi datangnya AEC. Untuk itu, pengembangan kewirausahaan yang selama 
Tabel 3. Kemampuan Berwirausaha Indonesia dan Beberapa Negara Kawasan ASEAN

\begin{tabular}{cccccc}
\hline \multirow{2}{*}{ Variabel } & \multicolumn{5}{c}{ Negara } \\
\cline { 2 - 6 } & Indonesia & Malaysia & Thailand & Phillipina & Singapura \\
\hline Peringkat dan Koefisien & $75-79$ & $55-57$ & $64-65$ & $91-92$ & $11-13$ \\
GEDI & $(0,21)$ & $(0,27)$ & $(0,24)$ & $(0,17)$ & $(0,53)$ \\
\hline Entrepreneurial & $95-96$ & $58-59$ & $83-84$ & $64-66$ & $27-29$ \\
Attitudes & $(0,18)$ & $(0,32)$ & $(0,24)$ & $(0,29)$ & $(0,43)$ \\
\hline \multirow{2}{*}{ Entrepreneurial Ability } & $46-55$ & $38-39$ & $44-45$ & $92-99$ & $12-14$ \\
\hline Entrepreneurial & $(0,30)$ & $(0,35)$ & $(0,31)$ & $(0,17)$ & $(0,58)$ \\
Aspirations & $66-72$ & $73-79$ & $61-64$ & $110-114$ & \multirow{2}{*}{$3(0,56)$} \\
\hline
\end{tabular}

Sumber: Global Entrepreneurship and Development Index, 2013

ini sudah berjalan, baik di lingkup lembaga pemerintahan, di masyarakat, dan di kampus perlu lebih diintensifkan.

Bagaimanakah potret kewirausahaan Indonesia dibandingkan dengan beberapa negara di kawasan ASEAN? Data berikut ini menggambarkan kemampuan berwirausaha Indonesia dibandingkan dengan beberapa negara di kawasan ASEAN terpilih, yang berpotensi menjadi pesaing utama Indonesia dalam kancah persaingan di tingkat ASEAN. Data diambil dari Global Entrepreneurship and Development Index tahun 2013.

Peringkat kewirausahaan Indonesia unggul dibandingkan dengan Phillipina, tetapi berada di bawah Singapura, Malaysia, dan Thailand. Dalam pengembangan kewirausahaan, Indonesia lemah dari sisi proses inovasi, kualitas sumber daya manusia, faktor budaya, program pengembangan kewirausahaan, kualifikasi pendidikan, risiko bisnis, pemanfaatan teknologi internet, tingkat korupsi, kesiapan menghadapi era global, ketrampilan memulai usaha, keberanian menghadapi risiko kegagalan, kemampuan membangun jejaring, ketersediaan sumber daya, kemampuan produktivitas, dan orientasi global. Lima variabel yang meliputi: proses inovasi, kualitas sumber daya manusia, faktor budaya, program pengembangan kewirausahaan, dan kualifikasi pendidikan merupakan titik lemah utama yang membuat spirit entrepreneurship belum mengakar kuat di Indonesia. Indonesia dinilai berpeluang untuk berkembangnya kegiatan kewirausahaan berkaitan dengan potensi pasar yang besar dan berkembangnya teknologi baru yang mendukung kegiatan kewirausahaan. Keunggulan beberapa negara tetangga (misalnya Malaysia dan Thailand) dibandingkan dengan Indonesia adalah terletak pada faktor kemampuan berkompetisi, kemampuan membangun jejaring, kemampuan memulai usaha, dominasi pasar, ketersediaan sumber daya manusia yang terampil dan terlatih, kualitas SDM, kemampuan berinovasi, dan risiko bisnis yang lebih rendah (GEDI, 2013).

Dengan demikian dapat diidentifikasi bahwa secara head to head indeks kewirausahaan Indonesia adalah relatif unggul dibandingkan dengan Phillipina, relatif setara dengan Thailand; tetapi 
tertinggal dibandingkan dengan Malaysia dan Singapura. Kewirausahaan merupakan faktor penting yang akan menentukan apakah sebuah negara mampu bersaing dalam pasar global. Dengan memperhatikan posisi peringkat kewirausahaan Indonesia dibandingkan dengan negara ASEAN terpilih, maka Indonesia harus berjuang keras untuk menghadapi Singapura, Malaysia, dan Thailand dalam AEC. Untuk memperkuat posisi Indonesia dalam AEC, Indonesia harus meningkatkan kemampuan dalam bidang kewirausahaan. Di tangan para pewirausaha inovasi akan terus tumbuh dan kegiatan ekonomi akan terus berkembang.

\section{PENGUATAN INOVASI UNTUK MENDUKUNG KEWIRAUSAHAAN}

Daya saing bangsa juga ditentukan oleh kemampuan melakukan inovasi. Rendahnya dana yang dialokasikan untuk kegiatan penelitian dan pengembangan menjadi salah satu faktor yang menyebabkan rendahnya kemampuan untuk melakukan inovasi. Para pewirausaha di Indonesia belum mampu bergerak pada bidang usaha yang sarat dengan teknologi dan inovasi. Hingga kini, bidang garapan para pewirausaha di Indonesia masih berada pada sektor bisnis ritel, industri makanan dan olahan, jasa perikanan, pertanian, dan pertambangan. Dalam tahun 2012, sebanyak 57\% GDP Indonesia disumbang oleh kegiatan usaha para pewirausaha di berbagai sektor tersebut (The EY G20 Entrepreneurship Barometer 2013).

Pendidikan di Indonesia dinilai belum mampu menciptakan budaya inovasi yang kuat, sebuah kondisi yang dibutuhkan bagi tumbuhnya budaya wirausaha. Terdapat situasi yang paradoksal dalam perekonomian Indonesia. Pada saat pertumbuhan ekonomi Indonesia tumbuh dengan cepat, namun pada saat yang sama peran pendidikan dalam melahirkan para pewirausaha baru masih sangat lemah. Kebanyakan lulusan pendidikan menengah dan pendidikan tinggi belum memiliki spirit yang kuat untuk menjadi pewirausaha. Setelah lulus pendidikan, umumnya mereka masuk ke pasar kerja untuk mencari kerja, dan bukan menciptakan pekerjaan (www.worldbank. org). Sebagaimana dilaporkan dalam "The EY G20 Entrepreneurship Baromater 2013", kegiatan pendidikan dan latihan; terutama yang diarahkan untuk menumbuhkan spirit berwirausaha; dinilai masih sangat lemah. Lemahnya kegiatan pendidikan dan latihan berdampak lemahnya budaya berwirausaha dalam kehidupan bermasyarakat di Indonesia (www.ey.com).

Untuk melihat sejauh mana pemerintah memperkuat budaya wirausaha sebagai lifestyle baru, terutama bagi kelompok penduduk usia muda; Bank Dunia menggunakan ukuran besaran pengeluaran untuk kegiatan penelitian dan pengembangan (R\&D) dan artikel dalam bidang ilmu pengetahuan dan teknologi yang dipublikasikan pada jurnal. Sebagai gambaran, pengeluaran untuk R\&D Indonesia adalah 0,1\% dari total GDP; dan ini di bawah rata-rata pengeluaran dari negara anggota G20 lainnya sebesar 1,6\% dari total GDP. Jumlah publikasi di bidang ilmu pengetahuan dan teknologi Indonesia adalah 0,0 artikel per 10.000 penduduk. Bandingkan dengan negara anggota G20 lainnya yang mencapai 3,3 artikel per 10.000 penduduk (www.ey.com). 
Tabel 4. Pengeluaran Negara Anggota ASEAN Terpilih untuk R\&D (\% dari PDB)

\begin{tabular}{cccc}
\hline \multirow{2}{*}{ Negara } & \multicolumn{3}{c}{ Tahun } \\
\cline { 2 - 4 } & $\mathbf{2 0 0 9}$ & $\mathbf{2 0 1 0}$ & $\mathbf{2 0 1 1}$ \\
\hline Indonesia & 0,08 & - & - \\
Malaysia & 1,01 & 1,07 & 1,07 \\
Thailand & 0,25 & - & - \\
Singapura & 2,43 & 2,09 & - \\
\hline
\end{tabular}

Sumber: www.worldbank.org

Bank Dunia memberikan data proporsi pengeluaran terhadap PDB untuk kegiatan R\&D, sebagaimana tampak pada Tabel 4 . Pengeluaran negara untuk kegiatan R\&D akan berdampak pada kemampuan negara untuk mengembangkan inovasi (Ulku, 2004). Dari berbagai kajian teoretik dan hasil penelitian dapat dikemukakan bahwa kemampuan berinovasi dan kreativitas merupakan salah satu variabel utama pembentuk perilaku kewirausahaan (Drucker, 1985; Baron, 2004; Zampetakis, Gotsi, Andriopoulos \& Moustakis, 2011). Malaysia, Thailand, dan Singapura memiliki pengeluaran untuk R\&D lebih tinggi dari Indonesia, dan hal ini terbukti berdampak pada peringkat kewirausahaannya yang lebih tinggi dari Indonesia.

Studi yang dilakukan oleh Ulku (2004) pada berbagai negara di dunia menemukan bahwa R\&D merupakan faktor utama yang menumbuhkan inovasi, dan inovasi yang berkembang dengan baik terbukti mampu menciptakan pertumbuhan ekonomi yang berkelanjutan. Kajian yang dilakukan Yanyun dan Mingqian dari The Center for Applied Statistics, Renmin University of China (www.kdi.re.kr/upload); juga menemukan adanya keterkaitan yang sangat kuat antara pengeluaran negara untuk R\&D dengan terciptanya pertumbuhan ekonomi.

\section{PEMANFAATAN IT DALAM KEGIATAN}

\section{USAHA}

Dalam era sekarang, kualitas kewirausahaan suatu bangsa dapat diukur dari familiaritas penduduk dalam memanfaatkan teknologi informasi untuk kegiatan bisnis. Pemanfaatan teknologi informasi memungkinkan terciptanya efisiensi ekonomi dan meningkatkan produktivitas. Data pada Tabel 5 menggambarkan

Tabel 5. Indeks Kemampuan Membangun Jejaring

\begin{tabular}{cccc}
\hline $\begin{array}{c}\text { Peringkat 2013 } \\
\text { (dari 144 Negara) }\end{array}$ & Negara & Koefisien Indeks & $\begin{array}{c}\text { Peringkat 2012 } \\
\text { (dari 142 Negara) }\end{array}$ \\
\hline 2 & Singapura & 5.98 & 3 \\
30 & Malaysia & 4.82 & 29 \\
57 & Brunei & 4.11 & 54 \\
74 & Thailand & 3.87 & 77 \\
76 & Indonesia & 3.84 & 80 \\
84 & Vietnam & 3.74 & 83 \\
86 & Phillipina & 3.73 & 86 \\
\hline
\end{tabular}

Sumber: The Global Information Technology Report, 2013; WEF 2013 
Tabel 6. Indeks Pemanfaatan IT Beberapa Negara ASEAN

\begin{tabular}{ccccccccc}
\hline \multirow{2}{*}{ Rank } & \multirow{2}{*}{ Negara } & Skor & \multicolumn{2}{c}{ Individual Usage } & \multicolumn{2}{c}{ Business Usage } & \multicolumn{2}{c}{$\begin{array}{c}\text { Goverment } \\
\text { Usage }\end{array}$} \\
\cline { 3 - 8 } & & & Rank & Skor & Rank & Skor & Rank & Skor \\
\hline 3 & Singapura & 5.86 & 11 & 6.13 & 14 & 5.18 & 1 & 6.29 \\
29 & Malaysia & 4.83 & 46 & 4.44 & 26 & 4.49 & 7 & 5.57 \\
41 & Brunei & 4.21 & 49 & 4.32 & 59 & 3.56 & 33 & 4.75 \\
70 & Indonesia & 3.58 & 92 & 2.74 & 40 & 3.81 & 58 & 4.20 \\
73 & Vietnam & 3.52 & 78 & 3.08 & 88 & 3.30 & 62 & 4.16 \\
76 & Philipina & 3.46 & 95 & 2.69 & 47 & 3.65 & 67 & 4.04 \\
83 & Thailand & 3.39 & 88 & 2.84 & 63 & 3.50 & 86 & 3.84 \\
\hline
\end{tabular}

Sumber: The Global Information Technology Report, 2013; WEF 2013

kemampuan Indonesia dalam memanfaatkan teknologi informasi dalam rangka memperkuat jejaring kegiatan usaha bisnis dibandingkan dengan negara-negara ASEAN.

Secara head to head dengan sesama negara anggota ASEAN, Indonesia pada posisi relatif setara dengan Thailand, relatif unggul di atas Vietnam dan Phillipina; tetapi berada di bawah Singapura, Malaysia, dan Brunei Darusalam. Meskipun demikian, Indonesia berpotensi untuk memperbaiki posisi karena dari sisi pemanfaatan IT Indonesia lebih unggul dibandingkan dengan Vietnam, Phillipina, dan Thailand. Tabel 6 menjelaskan peringkat pemanfaatan IT dibandingkan dengan beberapa negara di kawasan ASEAN.

Perangkat IT oleh lembaga bisnis di Singapura dan Malaysia jauh lebih intensif dibandingkan dengan Indonesia. Dilihat dari skor indeks, bisa dikatakan intensitas pemanfaatan IT di Singapura dan Malaysia dua kali lipat dibandingkan dengan Indonesia. Hal yang sama juga terjadi pada lembaga pemerintahan, di mana Indonesia menduduki posisi keempat di bawah Singapura, Malaysia, dan Brunei. Sedangkan pemanfaatan IT oleh individu di Indonesia jauh tertinggal dibandingkan dengan Singapura, Malaysia, Brunei, Vietnam, dan Thailand. Pemanfaatan IT oleh individu di Indonesia hanya unggul dibandingkan dengan Phillipina.

Pemanfaatan IT secara intensif akan mempengaruhi kegiatan bisnis. Semakin intensif pemanfaatan IT pada sebuah negara, maka kegiatan bisnis di negara tersebut akan semakin berkembang. Berkembangnya kegiatan bisnis menandakan berkembangnya budaya kewirausahaan, dan hal ini akan mempengaruhi kehidupan sosial.

Tabel 7 menjelaskan pemanfaatan IT di Indonesia dan dampaknya terhadap kegiatan sosial dan ekonomi. Data tersebut menunjukkan posisi Indonesia masih berada di bawah Singapura, Malaysia, dan Brunei; serta di atas Vietnam, Phillipina, dan Thailand; namun pemanfaatan IT baik oleh individu, lembaga bisnis, dan lembaga pemerintahan belum memberikan dampak sosial ekonomi yang optimal. Dampak pemanfaatan IT terhadap aktivitas ekonomi masih menempatkan Indonesia berada di bawah Singapura, Malaysia, Brunei, Phillipina, dan Vietnam. Sedangkan dampak 
Tabel 7. Pemanfaatan IT dan Dampaknya Terhadap Dimensi Sosial Ekonomi

\begin{tabular}{cllcccc}
\hline \multirow{2}{*}{ Rank } & \multirow{2}{*}{ Negara } & \multirow{2}{*}{ Skor } & \multicolumn{2}{c}{ Dampak Ekonomi } & \multicolumn{2}{c}{ Dampak Sosial } \\
\cline { 4 - 7 } & & & Rank & Skor & Rank & Skor \\
\hline 1 & Singapura & 6.13 & 2 & 5.98 & 1 & 6.28 \\
27 & Malaysia & 4.52 & 29 & 4.02 & 25 & 5.02 \\
39 & Brunei & 4.07 & 48 & 3.43 & 35 & 4.71 \\
68 & Phillipina & 3.50 & 56 & 3.37 & 76 & 3.62 \\
75 & Vietnam & 3.39 & 89 & 2.97 & 64 & 3.81 \\
86 & Indonesia & 3.30 & 101 & 2.85 & 72 & 3.74 \\
88 & Thailand & 3.28 & 108 & 2.77 & 72 & 3.74 \\
\hline
\end{tabular}

Sumber: The Global Information Technology Report, 2013; WEF 2013

pemanfaatan IT bagi terbangunnya kehidupan sosial masih menempatkan Indonesia sejajar dengan Thailand, dan berada di bawah Singapura, Malaysia, Brunei, dan Vietnam. Berbagai fakta tersebut menunjukkan bahwa keberadaan IT di Indonesia belum mampu dimanfaatkan untuk kegiatan yang lebih produktif.

Kemampuan Indonesia dalam memanfaatkan IT guna mendukung kemampuan memperebutkan peluang pasar terlihat berada di bawah Singapura, relatif setara dengan Malaysia dan Thailand; dan relatif unggul dibandingkan dengan Vietnam. Indonesia harus memperkuat sarana infrastruktur di bidang IT untuk mendukung tumbuh suburnya budaya wirausaha.

\section{PERBANDINGAN DAYA SAING INDONESIA DENGAN NEGARA ASEAN TERPILIH}

Berdasarkan paparan data di atas, maka dibuat perbandingan daya saing Indonesia dengan Negara ASEAN lainnya. Sebagai perbandingan pertama, Malaysia pada tahun 2013 memiliki daya saing pada peringkat 24 (dari 148 negara). Malaysia sampai dengan tahun 2013 dinilai telah mampu menciptakan efisiensi ekonomi, dan sedang berada pada masa transisi menuju pada perekonomian yang digerakkan oleh kekuatan inovasi (transisi dari grade 2 ke grade 3). Bukti bahwa Malaysia telah mampu menciptakan efisiensi dapat dilihat dari kegiatan memulai usaha bisnis hanya 3 prosedur (peringkat 10) dengan jumlah hari yang diperlukan hanya 6 hari (peringkat 16). Berbagai pilar penentu daya saing Malaysia juga jauh lebih baik dibandingkan dengan Indonesia (WEF, 2013). Keberhasilan Malaysia untuk melewati masa transisi menuju pada perekonomian yang digerakkan oleh inovasi akan memberikan kekuatan besar dalam menghadapi AEC. Secara head to head kualitas perekonomian Indonesia masih berada di bawah Malaysia. Artinya, dalam arena AEC Indonesia harus bersaing sangat keras dengan Malaysia untuk memperebutkan pasar.

Perbandingan kedua, Thailand pada tahun 2013 memiliki daya saing pada peringkat 37 (dari 148 negara). Peringkat daya saing Thailand berimbang dengan Indonesia yang berada pada peringkat 38 . Namun Indonesia berhasil melakukan lompatan peringkat sampai 12 level dari peringkat 50 pada tahun 2012, sedangkan Thailand naik satu level dari peringkat 38 pada tahun 2012. Hal ini menunjukkan 
bahwa perkembangan daya saing Indonesia menjadi lebih baik bila dibandingkan dengan Thailand. Sebagaimana Indonesia, perekonomian Thailand juga berada dalam tahap efisiensi ekonomi (grade 2). Lima faktor menyumbang lebih dari $70 \%$ yang menjadi penyebab terhambatnya kegiatan bisnis. Kelima faktor tersebut meliputi: korupsi $(20,2 \%)$, instabilitas pemerintahan $(16,5 \%)$, kebijakan pemerintah yang tidak stabil (13,5\%), inefisiensi birokrasi pemerintahan $(13,4 \%)$, dan keterbatasan kemampuan berinovasi (7,5\%). Thailand memiliki keunggulan dalam hal ukuran pasar (market size) pada peringkat 22, kondisi makro ekonomi pada peringkat 31, pasar keuangan peringkat 32, dan efisiensi pasar barang peringkat 34 . Ada 4 prosedur (peringkat 20) yang harus dilalui untuk memulai kegiatan bisnis dengan waktu yang diperlukan sebanyak 29 hari (peringkat 106) (WEF, 2013). Berdasarkan data-data tersebut, maka kemampuan perekonomian Indonesia dan Thailand relatif berimbang. Indonesia tentu memiliki keunggulan dalam hal ukuran pasar yang jauh lebih besar dibandingkan dengan Thailand. Dapat dikatakan, Thailand memiliki level yang relatif sama dengan Indonesia untuk menghadapi AEC.

Perbandingan ketiga, Vietnam pada tahun 2013 memiliki daya saing pada peringkat 70 (dari 148 negara). Vietnam berhasil melakukan lompatan peringkat 5 level dari peringkat 75 pada tahun 2012. Perekonomian Vietnam masih sangat tergantung pada ketersediaan faktor produksi (grade 1). Hingga saat ini keunggulan Vietnam hanya pada ukuran pasar (market size) yang berada pada peringkat 36. Selebihnya Vietnam masih harus berjuang keras untuk meningkatkan daya saing. Lima faktor menyumbang lebih dari $70 \%$ yang menjadi penyebab terhambatnya kegiatan bisnis. Kelima faktor tersebut meliputi: akses keuangan (18,4\%), kebijakan pemerintah tidak konsisten $(11,4 \%)$, keterbatasan tenaga kerja terdidik (10\%), inflasi $(9,9 \%)$, dan keterbatasan sarana infrastruktur, regulasi perpajakan, dan korupsi (25,2\%). Ada 10 prosedur (peringkat 116) yang harus dilalui untuk memulai kegiatan bisnis dengan waktu yang diperlukan sebanyak 34 hari (peringkat 114) (WEF, 2013). Berbagai data tersebut menunjukkan bahwa perekonomian Vietnam masih jauh dari efisien. Bila diukur pada saat ini, daya saing Vietnam dalam kancah AEC berada di bawah Malaysia, Indonesia, Thailand, dan Phillipina. Dengan demikian secara head to head kualitas perekonomian Indonesia relatif lebih unggul dibandingkan dengan Vietnam.

Perbandingan keempat, Phillipina pada tahun 2013 memiliki daya saing pada peringkat 59 (dari 148 negara). Bersama dengan Indonesia, Phillipina berhasil melakukan lompatan peringkat daya saing, karena pada tahun 2012 masih berada pada peringkat 65 (dari 144 negara), dan tahun 2011 pada peringkat 75 (dari 142 negara). Sampai dengan tahun 2013, Phillipina masih sedang berjuang untuk bertransisi dari perekonomian yang tergantung pada ketersediaan faktor produksi menuju pada efisiensi ekonomi (transisi dari grade 1 ke grade 2). Ada lima faktor yang membuat kegiatan bisnis di Phillipina menjadi tidak mudah. Kelima faktor tersebut bahkan menyumbang terjadinya kesulitan bisnis 
Tabel 8. Daya Tarik Negara ASEAN Di Mata Investor Global

\begin{tabular}{cccccc}
\hline Negara & $\begin{array}{c}\mathbf{2 0 1 1 - 2 0 1 4} \\
\mathbf{( \% )}\end{array}$ & Peringkat & Negara & $\begin{array}{c}\mathbf{2 0 1 3 - 2 0 1 5} \\
\mathbf{( \% )}\end{array}$ & Peringkat \\
\hline Singapura & 7,9 & 1 & Myanmar & 12,4 & 1 \\
Vietnam & 7,9 & 2 & Malaysia & 11,4 & 2 \\
Malaysia & 7,3 & 3 & Singapura & 8,1 & 3 \\
Thailand & 3,8 & 4 & Indonesia & 6,8 & 4 \\
Indonesia & 3,8 & 5 & Vietnam & 6,2 & 5 \\
Laos & 2,2 & 6 & Laos & 3,9 & 6 \\
Myanmar & 1,9 & 7 & Thailand & 3,3 & 7 \\
Kamboja & 0,6 & 8 & Kamboja & 3,3 & 8 \\
Phillipina & 0,6 & 9 & Phillipina & 1,3 & 9 \\
Brunei & 0,3 & 10 & Brunei & 0,3 & 10 \\
\hline Total & $\mathbf{3 7 , 5}$ & \multicolumn{5}{c}{ Total } \\
\hline
\end{tabular}

Sumber: 2011-12 \& 2013 ASEAN-BAC Survey On ASEAN Competitiveness

hingga lebih dari $70 \%$. Kelima faktor tersebut meliputi: sarana infrastruktur belum memadai $(21,1 \%)$, korupsi $(17,8 \%)$, inefisiensi birokrasi $(16,9 \%)$, regulasi perpajakan $(8,6 \%)$, dan regulasi perburuan yang tidak kondusif (8,4\%). Ada 16 prosedur (peringkat 145) yang harus dilalui untuk memulai kegiatan bisnis dengan waktu yang diperlukan sebanyak 36 hari (peringkat 118) (WEF,2013). Berbagai faktor inilah yang menyebabkan Phillipina belum mampu mencapai efisiensi ekonomi. Problem di Phillipina sebenarnya hampir sama dengan di Indonesia, namun Indonesia beruntung memiliki ukuran pasar yang sangat besar dan mampu menciptakan kondisi makro ekonomi yang relatif stabil. Dengan demikian secara head to head kualitas perekonomian Indonesia relatif lebih unggul dibandingkan dengan Phillipina.

Dengan menggunakan berbagai parameter yang dikeluarkan oleh WEF 2013, maka secara head to head daya saing Indonesia masih berada di bawah Singapura dan Malaysia, selevel dengan Thailand, dan berada di atas Phillipina dan Vietnam. Dapat dikatakan, pesaing utama Indonesia pada AEC nanti adalah Singapura, Malaysia, dan Thailand. Meskipun demikian, Vietnam dan Myanmar akan menjadi ancaman serius, karena akir-akhir ini mulai mampu menarik minat para investor global untuk menanamkan kegiatan investasinya (201112 \& 2013 ASEAN-BAC Survey On ASEAN Competitiveness).

Tabel 8 menggambarkan bahwa daya tarik Indonesia di mata investor global berada di bawah Singapura, Vietnam, dan Malaysia. Pada tahun 2012, daya tarik Indonesia sejajar dengan Thailand, dan berada di atas Laos, Myanmar, Kamboja, Phillipina, dan Brunei. Sedangkan tahun 2013, daya tarik Indonesia berada di bawah Myanmar, Malaysia, Singapura; tetapi berada di atas Vietnam, Thailand, Laos, Kamboja, Phillipina, dan Brunei.

Malaysia dan Singapura adalah dua negara ASEAN yang konsisten mampu menarik para investor global. Negara ASEAN yang mengalami peningkatan daya tarik adalah Myanmar dan Indonesia. Negara 
ASEAN yang mengalami penurunan daya tarik adalah Vietnam dan Thailand. Meskipun demikian, pada tahun 2011 Vietnam juga secara fenomenal mampu mengungguli Malaysia dalam menarik investor global. Sedangkan negara ASEAN yang tetap dinilai kurang menarik oleh para investor adalah Laos, Kamboja, Phillipina, dan Brunei. Selain Indonesia, Myanmar merupakan negara di ASEAN yang paling fenomenal dalam meningkatkan daya tarik bagi investor global. Hal ini menunjukkan bahwa ada upaya serius yang dilakukan oleh Myanmar untuk menghadapi persaingan.

Data-data terdahulu seolah-olah menunjukkan bahwa persaingan dalam masyarakat ASEAN cenderung hanya melibatkan Malaysia, Thailand, Indonesia, dengan Singapura sebagai top leader. Kini muncul negara Vietnam dan Myanmar yang mulai mampu mengusik kemapanan Malaysia, Thailand, dan Indonesia dalam urusan membangun daya tarik kegiatan investasi. Dengan kata lain, dalam AEC nanti selain harus bersaing keras dengan Singapura, Malaysia, Thailand; Indonesia akan mendapatkan tekanan yang kuat dari Vietnam, Myanmar, dan Phillipina. Bila menggunakan parameter tahun 2013, pada saat ini daya saing Indonesia berada di bawah Singapura dan Malaysia, sejajar dengan Thailand; tetapi berada pada di atas negara anggota ASEAN lainnya.

\section{SIMPULAN}

Berdasarkan sajian berbagai data tentang kinerja perekonomian Indonesia dan berbagai variabel yang mempengaruhi daya saing negara-negara di kawasan ASEAN, maka dapat disimpulkan sebagai berikut:
1. Hingga saat ini, Indonesia adalah merupakan negara yang memiliki ukuran pasar paling besar di kawasan ASEAN. Dengan proporsi jumlah penduduk dan GDP mencapai $40 \%$ dari total penduduk dan GDP negara ASEAN, dan didukung dengan rerata pendapatan per kapita lebih dari \$3.500 (kelompok negara berpendapatan menengah), membuat Indonesia ibarat sebuah pasar yang berukuran jumbo. Pertumbuhan ekonomi positif selama beberapa tahun terakhir membuat Indonesia berpotensi menjadi pusat bisnis di kawasan ASEAN.

2. Meningkatnya rerata pendapatan per kapita penduduk Indonesia telah meningkatkan daya beli masyarakat. Konsumsi nasional meningkat sangat pesat, dan hal ini menjadi salah faktor yang menggerakkan perekonomian nasional. Peningkatan konsumsi nasional juga membuka peluang usaha yang sangat besar. Negara-negara ASEAN telah memanfaatkan peluang pasar ini yang ditandai dengan membanjirkan produk-produk barang impor ke dalam pasar di Indonesia. Hal ini mengindikasikan ada persoalan daya saing yang dialami oleh pelaku usaha di dalam negeri.

3. Indonesia harus berupaya keras untuk memperkuat budaya wirausaha. Peningkatan produktivitas dan kemampuan menciptakan produk berkualitas akan digerakkan oleh para pewirausaha. Tingkat produktivitas sangat berkaitan dengan kegiatan research and development (R\&D). R\&D merupakan pilar utama dari inovasi, dan kemampuan berinovasi akan 
mempengaruhi terciptanya budaya wirausaha. Di kawasan ASEAN, budaya wirausaha Indonesia masih kalah jauh dibandingkan dengan Singapura, Malaysia, dan Thailand. Hal ini menjadi tantangan bagi Indonesia untuk memperkuat budaya wirausaha. Untuk menghadapi AEC, negara dengan budaya wirausaha yang kuat merupakan persyaratan utama harus bisa dipenuhi. Budaya wirausaha yang kuat merupakan salah satu faktor utama pembentuk daya saing bangsa

4. Kualitas kewirausahaan pada sebuah negara berkaitan erat dengan kemampuan memanfaatkan IT untuk membangun jejaring usaha dan meningkatkan produktivitas. Sarana IT membuat berbagai aktivitas bisnis akan dapat berjalan dengan cepat, efektif, dan efisien. Penguasaan IT yang optimal oleh para pewirausaha akan memungkinkan mereka untuk menangkap peluang usaha. Indonesia harus mendorong para warganya untuk memanfaatkan IT untuk meningkatkan produktivitas kerja, menciptakan efektivitas dan efisiensi kerja; sehingga dapat tercipta daya saing.

5. Kemampuan Indonesia untuk berkiprah dalam era AEC dapat dipotret dari daya saing Indonesia pada saat ini dibandingkan dengan negara-negara di kawasan ASEAN. Daya saing Indonesia pada saat ini berada di bawah Singapura dan Malaysia, relatif setara dengan Thailand; dan relatif unggul dibandingkan dengan negara ASEAN lainnya.

Beberapa saran yang diajukan adalah sebagai berikut:
1. Pelaku usaha di dalam negeri harus memahami, mengerti, dan mengetahui berbagai konsekuensi hadirnya era AEC. Untuk itu, pemerintah perlu berkomunikasi lebih intensif dengan para pelaku usaha tentang segala hal yang berkaitan dengan AEC. Potensi pasar di dalam negeri yang sangat besar, seiring dengan meningkatnya GDP dan IPC; tidak akan memberikan manfaat optimal bagi perekonomian nasional apabila para pelaku usaha di dalam negeri kalah bersaing dengan pelaku usaha dari negara lain. Oleh karena itu semua pihak, baik pemerintah maupun pelaku usaha harus terus berupaya untuk meningkatkan daya saing.

2. Budaya wirausaha harus diperkuat dan dijadikan lifestyle baru dalam kehidupan masyarakat. Pemerintah bersama-sama dengan segenap komponen masyarakat, terutama lembaga pendidikan tinggi harus memiliki program riil untuk memperkuat budaya wirausaha. Penguatan budaya wirausaha harus dilaksanakan secara masif, dan menjadi program nasional yang menyentuh sampai level pelosok desa; sebagaimana pemerintah melaksanakan program keluarga berencana pada masa lampau.

3. Institusi pendidikan tinggi harus mengambil peran nyata untuk meningkatkan daya saing bangsa, ikut menumbuhkan budaya wirausaha bagi para mahasiswanya, dan meningkatkan kegiatan penelitian dan pengembangan guna menciptakan inovasi guna ikut mendorong tumbuh suburnya budaya wirausaha. 
4. Pemerintah harus memiliki komitmen kuat untuk menciptakan kondisi yang memungkinkan berkembangnya budaya wirausaha. Hal ini dapat dilakukan dengan memperluas dan memperkuat jaringan IT dan menyediakan dana yang memadai untuk berkembangnya kegiatan inovasi melalui kegiatan penelitian dan pengembangan.

\section{DAFTAR PUSTAKA}

Aaron Flaaen, Ejaz Ghani, \& Saurabh Mishra. (2013) "How to avoid middle-income traps? Evidence from Malaysia", dalam www.voxeu.org, diakses 2/12/2013

ASEAN. (2014) ASEAN Economic Community (AEC) Blueprint, dalam www.asean.org/communities, diakses 2/1/2014

Asnet. (2013) R \& D in ASEAN, dalam www.asnet.asean.org, $12 / 12 / 2013$

Bank Dunia. (2013) Worldwide Governance Indicators, www.data.bankdunia.org, diakses $1 / 10 / 2013$

Baron, R.A. (2004) The Cognitive Perspective: A Valuable Tool for Answering Entrepreneurship's Basic "Why" Question. Journal of Business Venturing. Vol. 19 pp. 221-239

BBC. (2013) Pertumbuhan Ekonomi Indonesia Capai Angka Tertinggi-BBC Indonesia, dalam www.bbc.co.uk , diakses 19/12/2013

Berita Resmi Statistik. (2013) Ekspor dan Impor Indonesia, dalam Berita Resmi Statistik No. 49/Th.XVI, 1 Agustus 2013

Beritasatu. (2013) Persiapan Indonesia Menghadapi Pasar Bebas ASEAN Masih Belum Optimal, dalam www.m.beritasatu.com/ekonomi, diakses 18/12/2013

Bisnis. (2013) Kewirausahaan Indonesia Dan Negara ASEAN, dalam www.bisnis.com, diakses 28/12/2013

BPS (2013) Data Ekspor dan Impor Indonesia, www.bps.go.id , diakses 14/11/2013

BPS (2013) Jumlah Angkatan Kerja 2013 Capai 118,2 Juta, dalam www.investor.co.id, diakses 9/1/2014

BPS. (2013) Jumlah Penduduk Miskin Sampai September 2013 Capai 28,55 Juta, dalam www.bps.go.id, diakses 8/1/2014

BPS. (2013) Pertumbuhan Ekonomi Indonesia 2013, dalam www.bps.go.id, diakses 20/12/2013

Drucker, P.F. (1985) Innovation and Entrepreneurship. New York: Harper \& Row

Etc-thai. (2012) Thailand 2012: The Year of English Speaking, dalam www.etcthai.com, diakses 8/11/2013

Ey. (2013) The EY G20 Entrepreneurship Baromater 2013, dalam www.ey.com, diakses 3/1/2014

Icird. (2013) Assesing the Integration of Vietnam's Distribution Services in AEC, dalam www.icird.org, diakses 2/12/2013

IMF. (2011) GDP and IPC Data in 2011, dalam www.imf.org, diakses 9/11/2012

Investor. (2013) Kelas Menengah Capai 60\% Penduduk Indonesia, dalam www.investor.co.id , diakses 14/12/2013

Kpmg. (2013) 2013 Change Readiness Index, Assesing Countries' Ability to Manage Change and Cultivate Opportunity, dalam www.kpmg.com/global, diakses $2 / 1 / 2014$

Kriengsak. (2013) Thailand's Readiness for the ASEAN Economic Community, dalam www.kriengsak.com, diakses 20/12/2013 
Lkyspp. (2012) 2011-12 \& 2013 ASEAN-BAC Survey On ASEAN Competitiveness, dalam www.lkyspp.nus.edu.sg/2013ASEAN-BAC-Survey, diakses 3/1/2014

Okezone. (2013) Investasi Asing Terus Tumbuh, dalam www.m.okezone.com, diakses 11/11/2013

Pikiran Rakyat. (2014) Kewirausahaan Indonesia Tertinggal, dalam www.pikiran-rakyat.com, diakses $7 / 1 / 2014$

Ppusdatinaker (2013) Pengangguran Terbuka Nasional Menurut Pendidikan dan Lokasi tempat Tinggal, dalam www.pusdatinaker.balitfo.depnakertran s.go.id, diakses 12/12/2013

Prosperity. (2013) The 2011 Legatum Prosperity Index, dalam www.prosperity.com/rankings.aspx, diakses, 13/12/2013

Republika. (2013) Jumlah Penduduk Indonesia 2013 diperkirakan 250 juta jiwa, www.republika.co.id, diakses $11 / 12 / 2013$

Seneviratne, Dulani and Sun, Yan. 2013. Infrastructure and Income Distribution in ASEAN-5: What are the link. IMF Working Paper

Tempo. (2013) Kelas menengah Indonesia Akan Melonjak 250\%, dalam www.tempo.com, diakses 21/11/2013

Thegedi. (2014) Global Entrepreneurship and Development Index, 2013, dalam www.thegedi.org, diakses 3/1/2014

Tribunnewes. (2014) TPT Sampai Dengan Agustus 2013 6,25\%, dalam www.tribunnews.com, diakses 8/1/2014

Tribunnews. (2014) Pengangguran di Indonesia Mencapai 7,39 Juta, dalam www.tribunnews.com, diakses 6/1/2014

Ulku, Hulya. (2004) R\&D, Innovation, and Economic Growth: An Empirical Analysis.
IMF Working Paper, dalam www.imf.org , diakses 7/1/2014

UNESCO. (2013) UNESCO Institute for Statistics, July 2011, dalam www.en.unesco.org, diakses 3/3/2012

Unescobkk. (2013) Entrepreneurship in Indonesia: The Importance of Educational institutions, dalam www.unescobkk.org/education, diakses 20/10/2013

Veteransbank. (2013) PHL Urged to Be Ready for ASEAN Integration dalam www.veteransbank.com, diakses 2/12/2013

Voxeu. (2013) How to avoid middle-income traps? Evidence from Malaysia" www.voxeu.org, diakses 23/7/2013

Weforum. (2013) The Global Information Technology Report, 2013, WEF 2013, dalam www.weforum.org/reports, diakses $1 / 1 / 2014$

Weforum. (2013) The Travel \& Tourism Competitiveness Report 2013, WEF 2013, dalam www.weforum.org/reports , diakses $1 / 1 / 2014$

Wikipedia. (2013) G20 Major EconomiesWikipedia, The Free Encyclopedia, dalam www.en.wikipedia.org, diakses 20/10/2013

Worldbank. (2010) GDP (current US\$) Data in 2010, dalam www.worldbank.org, diakses 11/11/2013

Worldbank. (2012) Research dan Development Expenditure \% to GDP, dalam www.worldbank.org, diakses $17 / 11 / 2012$

Yanyun, Zhao; Mingqiang, Zhang. Tanpa Tahun. R\&D and Economic Growth, Panel Data Analysis in ASEAN+3 Countries. The Center for Applied Statistics, Renmin University of China, dalam www.kdi.re.kr/upload, diakses 2/1/2014 
Jurnal Economia, Volume 11, Nomor 1, April 2015

Zampetakis, Leonidas A; Gotsi, Manto; Entrepreneurial Intention in Young Andriopoulos, Constantine \& Moustakis, Vassilis. (2011) Creativity and People. Entrepreneurship and Innovation. 12, 189-199 